\title{
Prospects and Challenges of Village Land Forest Reserves Management in Mbarali District, Tanzania
}

\author{
Anton C. Nzali*, Abiud Kaswamila \\ Department of Geography and Environmental Studies, The University of Dodoma, Dodoma, Tanzania \\ Email: ^antonzali@yahoo.com
}

How to cite this paper: Nzali, A. C., \& Kaswamila, A. (2019). Prospects and Challenges of Village Land Forest Reserves Management in Mbarali District, Tanzania. Open Journal of Forestry, 9, 159-167. https://doi.org/10.4236/ojf.2019.92007

Received: December 18, 2018

Accepted: April 8, 2019

Published: April 11, 2019

Copyright $\odot 2019$ by author(s) and Scientific Research Publishing Inc. This work is licensed under the Creative Commons Attribution International License (CC BY 4.0).

http://creativecommons.org/licenses/by/4.0/ c) (†) Open Access

\begin{abstract}
Prospects and challenges of Village Lands Forest Reserves (VLFRs) in Mbarali district, southern Tanzania were investigated. Data were collected through questionnaire surveys, in-depth key informant interviews, physical field visits and documentary reviews. A total of 44 subjects were involved in the study. SPSS, Microsoft Excel and content analysis were used in data analysis. Findings indicated that inadequate capacity building, passive community participation and involvement in VLFRs management fostered the continued forest degradation and deforestation in the study area. It was further observed that on average 2.04 ha of forest was being lost every year through anthropogenic activities, mainly farm expansion, charcoal business and firewood. In order to achieve VLFRs sustainability, the study recommends improvement of relationship and coordination among VLFRs key stakeholders, participatory preparation of forest management plans, enforcement of community forest management bylaws, and use of energy saving stoves to reduce overdependence on forests as source of energy.
\end{abstract}

\section{Keywords}

Village Land, Forest Reserve, Ruaha National Park, Mbarali District Council

\section{Introduction}

Deforestation and desertification in the world have accelerated despite a number of measures set to mitigate. An average of 10 million hectares disappears each year regardless of the international efforts to remedy it (FRA, 2011). Between 2000s and 2015, Africa (4 million ha) ranked second in deforestation after South America (3.4 million ha) of deforested land (Global Forest Resource Assessment, 
2010; FAO, 2015). The deforestation problem has resulted in an alarming transgression of a desert, such that, large parts of sub-Saharan Africa are predicted to become desert in the near future (Global Forest Resource Assessment, 2010; World Bank, 2010; World Bank, 2011). It has also been predicted that, forest deterioration impact will be more acute to the poor people of the south whose living depends solely on forests because desertification will affect soil quality and increase poverty (Luoga et al., 2002; Willy, 2006).

In Tanzania, major changes in political regimes and socio-economic policies of 1985-1995 which fostered widespread policy reform processes, and which were heavily backed by foreign donors, led to the wider promotion and adoption of VLFRs as a common Community Based Forest Management (CBFM) carried out in village lands (URT, 2007; Blomley \& Idd, 2009; Roe et al., 2009). Since its establishment, more than 3.6 million ha have come under community management or co-management between the community and local or central government till 2008 (Blomley \& Idd, 2009; Roe et al., 2009). According to Kajembe et al. (2005), despite the widespread of the participatory forest management within which CBFM systems are encompassed, little is clearly known about what has been achieved in terms of improvement of VLFRs themselves and the people's welfare. The national and local focus on forest protection rather than conservation has made CBFM unrealistic, hence accelerating deforestation, because the poor local communities, whose survival depends entirely on forest, are to protect them while also to a greater extent, also need of them (Kajembe et al., 2005; World Resource Institute, 2005).

Three Wards in Mbarali district have been implementing VLFRs for the past three decades. However, little is known about the challenges and strengths and weaknesses of VLFR management approaches in the area. The objective of this paper is to examine the challenges associated with sustainable management of VLFRs and to suggest measures which could make VLFRs sustainable.

\section{Methodology}

\subsection{The Study Area}

The Mabadaga, Itamboleo and Mbuyuni villages are administratively in Mbarali district (Figure 1), approximately between latitude $7^{\circ} 41^{\prime} 00^{\prime \prime}$ and $9^{\circ} 25^{\prime} 00^{\prime \prime S}$ and longitude $33^{\circ} 40^{\prime} 00^{\prime \prime}$ and $35^{\circ} 40^{\prime} 00^{\prime \prime} \mathrm{E}$. The study villages are within the eastern arm of the East African Rift valley, in Usangu plains approximately between latitude $8^{\circ} 53^{\prime}$ and $8^{\circ} 55^{\prime}$ south and longitude $33^{\circ} 53^{\prime}$ and $34^{\circ} 16^{\prime}$ east of equator. The study villages border Kipengele escarpment ranges.

The study area is a lowland plain (1000 - $1200 \mathrm{~m}$ asl) experiencing hot humid climate with unimodal rainfall. The main rain season is from December to April. The rainfall ranges between $800 \mathrm{~mm}$ and $650 \mathrm{~mm}$ per annum. The temperatures range between $25^{\circ} \mathrm{C}$ and $30^{\circ} \mathrm{C}$. The area is endowed with poorly drained gleyic luvisols and shallow alluvium over sodic lake bed. It is enriched with the poorly drained Eutric regosols, fluvisols and gleyic luvisols. Natural vegetation of the 


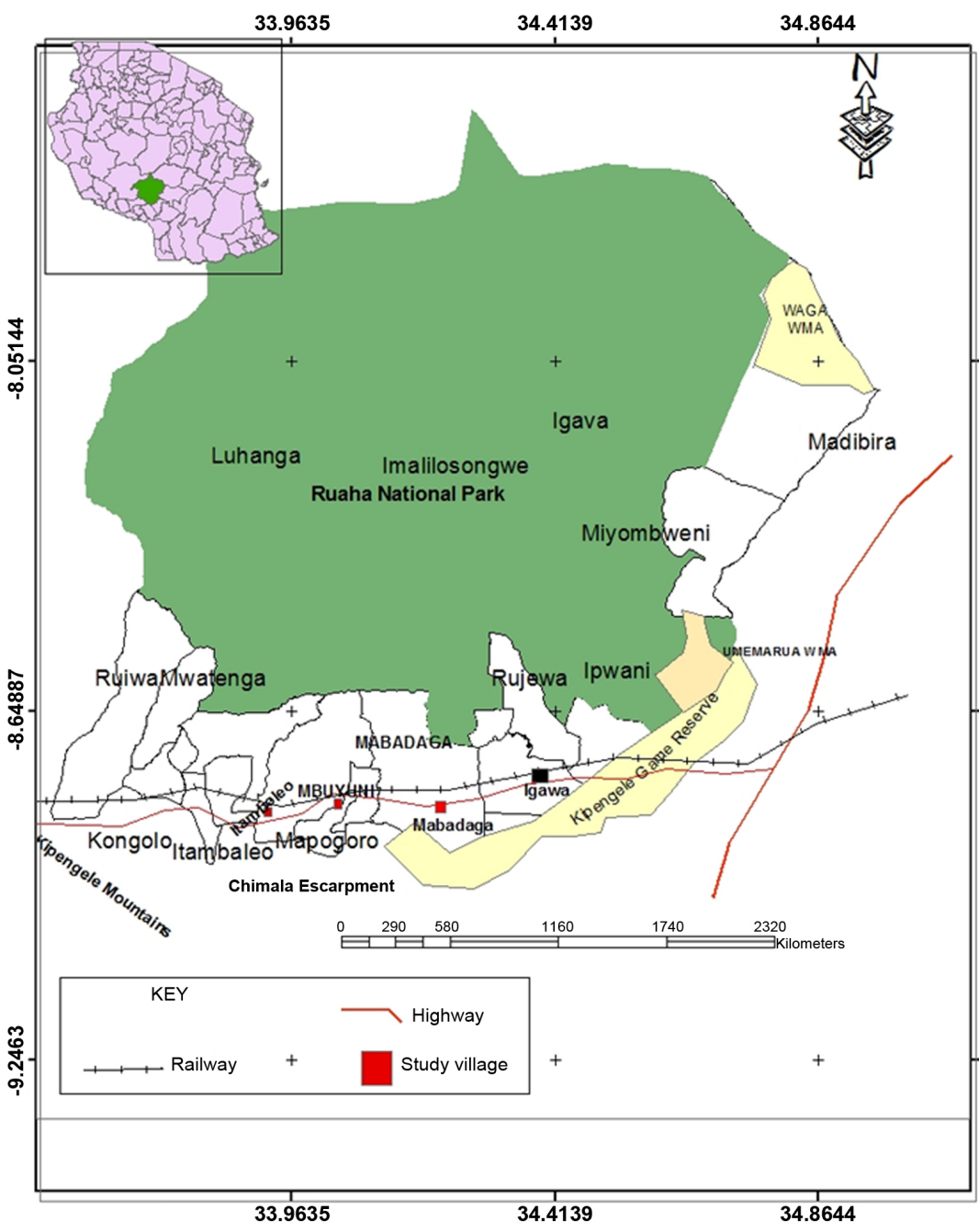

Figure 1. The study area. Source: Modified from Mbarali District Natural/Forests Office (2012).

area is savannah type with wooded grassland and thorny bushes. Due to its climate, soil nature and ecological characteristics, the main economic activity is agriculture, mainly paddy farming. Maize, groundnuts, beans and cattle keeping are also practiced.

\subsection{Data Collection Methods}

Different methods were used in data collection. The methods used were household questionnaire survey, in-depth key informant interviews, physical field visits and documentary reviews. The survey took three weeks. Self-administered structured questionnaires comprising of open and closed questions were administered to 30 randomly sampled households. The questions covered demographic characteristics, challenges of VLFR management, land use conflicts in the area, and suggestions for improving VLFRs management and sustainability. Before administering questionnaires to targeted respondents, questionnaires were pre-tested to ensure questions were well framed and easily understood. 
Ambiguous questions were later revised. A total number of key informants were also involved in the study. Physical field visits using the principle "walk, see and record" was organized in collaboration with village leaders. Data from questionnaires and interview schedules were examined and coded before importing into SPSS software. The key informants involved in the study included: District Lands and Natural Resources Officer, District Forest Officer, Ward Natural Resource Officers, Village Forest Extension Officers, Village Chairpersons, and Village Executive Officers. Data on degraded and deforested area was used in computing the size of land lost through deforestation and/or forest degradation. Qualitative data was analysed using content analysis and quantitative data was analysed with the help of SPSS software.

\section{Results and Discussion}

\subsection{Socio-Economic Profile of the Respondents}

The socio-economic information of respondents in the study area is presented in Table 1. Majority of the respondents involved in the study were males $(64.1 \%)$. The reasons for the high proportion to males could not be established. However, this could have happened by chance. As for age, $72 \%$ were youths. This implies that the population structure is stable and rich workforce. Regarding education, on average about $85 \%$ of respondents had primary school education level and a small proportion had secondary education and above. According to Ngailo and Kaswamila, 2011, this scenario looks normal in most Tanzanian villages. More than $67 \%$ of the respondents are involved in agriculture as their main economic activity.

\subsection{Challenges of Village Land Forest Reserve Management}

The challenges for VLFRs management in the three studied villages, that is, Madabaga, Mbuyuni and Itamboleo are presented in Table 2.

\subsubsection{Inadequate Funds for Village Land Forest Reserve Management} The financial and materials support was initially supported by Danish International Development Agency (DANIDA). After donor support VLFRs financial support banked on fines (charcoal makers and/or those caught cutting trees without the

Table 1. Socio-economic characteristics of the respondents.

\begin{tabular}{|c|c|c|c|c|c|c|c|c|c|c|c|c|}
\hline \multirow{2}{*}{ Village } & \multicolumn{2}{|c|}{$\operatorname{Sex}(\%)$} & \multicolumn{4}{|c|}{ Age (\%) } & \multicolumn{3}{|c|}{ Education (\%) } & \multicolumn{3}{|c|}{ Economic activities (\%) } \\
\hline & $\mathbf{M}$ & F & $18-25$ & $26-35$ & $36-45$ & $46+$ & $\operatorname{Pr}$ & $\mathrm{Sec}$ & As & $\mathrm{Ag}$ & Ptr & Ot \\
\hline Mabadaga $(\mathrm{n}=10)$ & 46.2 & 53.8 & 15.4 & 23.1 & 15.4 & 46.1 & 76.9 & 15.4 & 7.7 & 57.8 & 21.1 & 21.1 \\
\hline Mbuyuni $(\mathrm{n}=10)$ & 76.9 & 23.1 & 7.7 & 38.5 & 38.5 & 15.3 & 84.6 & 15.4 & n.r & 65 & 20 & 15 \\
\hline Itamboleo $(\mathrm{n}=10)$ & 69.2 & 30.8 & 7.7 & 23.1 & 46.1 & 23.1 & 92.3 & 7.7 & n.r & 78.7 & 14.3 & 7.14 \\
\hline Average & 64.1 & 35.9 & 10.3 & 28.2 & 33.4 & 28.2 & 84.6 & 12.9 & 7.7 & 67.2 & 18.5 & 14.4 \\
\hline
\end{tabular}

Notes: $\mathrm{M}=$ Male $\mathrm{F}$ = female $\mathrm{Pr}=$ Primary Education; $\mathrm{Sec}=$ Secondary Education; As = above secondary education; Ag = agriculture; Ptr = Pastoralist; Ot = others $\mathrm{n}=$ Sample size. 
Table 2. Challenges of VLFRs management in the study area.

\begin{tabular}{ccccc}
\hline Challenges & $\begin{array}{c}\text { Mabadaga } \\
(\mathrm{n}=10)\end{array}$ & $\begin{array}{c}\text { Mbuyuni } \\
(\mathrm{n}=10)\end{array}$ & $\begin{array}{c}\text { Itamboleo } \\
(\mathrm{n}=10)\end{array}$ & Average \\
\cline { 2 - 5 } & $(\%)$ & $(\%)$ & $(\%)$ & $(\%)$ \\
\hline Inadequate funds & 21.87 & 14.28 & 15.38 & 17.2 \\
Lack of cheap sources of energy & 14.55 & 16.32 & 15.38 & 15.44 \\
Population increase & 16.99 & 18.36 & 11.54 & 15.65 \\
Inadequate community involvement & 14.63 & 16.32 & 15.38 & 15.44 \\
Land conflicts & 12.19 & 14.28 & 17.31 & 14.59 \\
Inadequate government support & 20.0 & 8.16 & 11.54 & 13.23 \\
Inadequate forest staffs & $\mathrm{n} . \mathrm{r}$ & 12.24 & 13.46 & 8.57 \\
\hline
\end{tabular}

n.r $=$ not relevant

permission). For example, in two years the total funds collected Mabadaga and Itamboleo villages were Tshs. 612,250 and Tshs. 164,000. Other village sources of revenues was TANESCO power security fee, custom duty from local brewers and a $20 \%$ dividend from Tshs. 1500 imposed by the district council on each paddy bag. These funds are too little for any meaningful management of village forests.

\subsubsection{Population Increase}

Field data showed that the population of the study area continued to increase over years particularly in Madabaga and Mbuyuni (see Figure 2). This increase has implications on use of forest resources in particular as a source of reliable domestic energy source, timber and poles for construction purposes. In these villages about $97.5 \%$ of local community members use fuel wood as the only energy source for warming and heating. According to the Mbarali District Lands and Natural Resources Officer and the Madabaga Ward Natural Resource Officer, the population growth in the area is threatening the survival of all VLFRs in the district and efforts to retrogress the situation seem to be minute and inadequate. Ishengoma (1982) and Ahrends et al. (2010) had the views that firewood and charcoal making will continue to expand as the affordable alternatives run short and urban demand increases.

In an attempt to verify the extent to which the population impacted VLFRs through firewood and charcoal consumption; we observed that the study area consumed more than $14 \mathrm{~m}^{3} /$ year of fuel wood collected illegally from either VLFRs or from the neighbourhood Kituro Game Reserve (KGR) (Table 3).

According to the above data, fuel wood consumption is responsible for a loss of more than 20.35 ha from 2009 to 2013 , equivalent to 2.04 ha/year. Ishengoma (1982) and Lusambo et al. (2010) argue that fuel wood and charcoal have consistently been responsible for loss and threat to most forest in Tanzania, especially when not regulated. During our field visits we also observed heaps of woods cut from the VLFRs or surrounding reserves and piled-up in house compounds. Seventy six percent of households visited in the study area had piles of woods collected and left to dry for domestic use. 


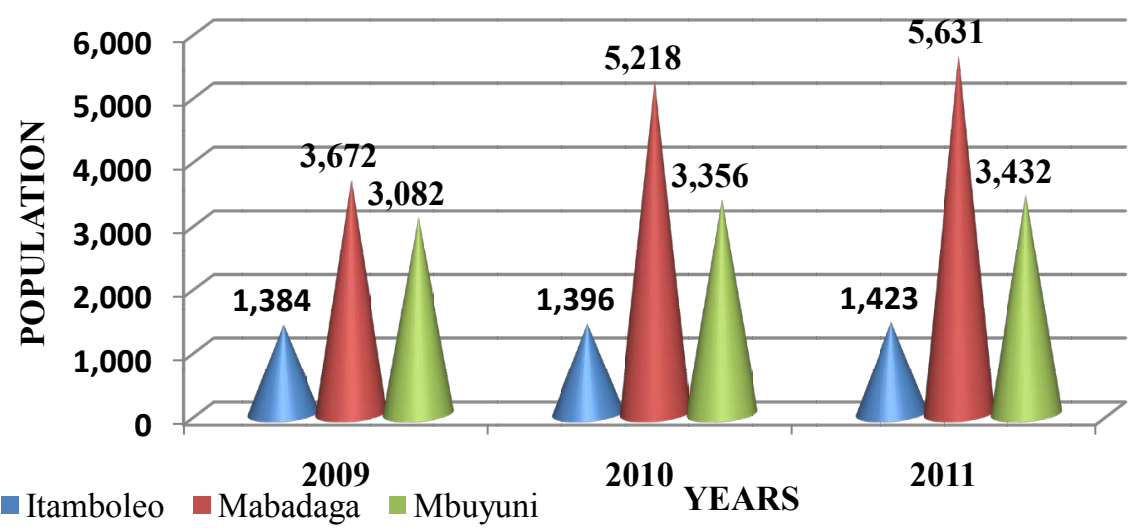

Figure 2. Population dynamics in the Study Villages.

Table 3. Impact of fuel wood consumption on forest reserves in the study area.

\begin{tabular}{cccccccccccc}
\hline \multirow{2}{*}{$\begin{array}{c}\text { Aspects } \\
\text { Year }\end{array}$} & \multicolumn{3}{c}{ Mabadaga } & \multicolumn{3}{c}{ Mbuyuni } & \multicolumn{3}{c}{ Itamboleo } & \multirow{2}{*}{ Total } & Avg \\
\cline { 2 - 10 } & 2009 & 2010 & 2011 & 2009 & 2010 & 2011 & 2009 & 2010 & 2011 & & \\
\hline Number of H/h & 367 & 522 & 560 & 308 & 336 & 343 & 138 & 140 & 142 & 4466 & 496.2 \\
$\Sigma \mathrm{M}^{3}$ & 9772 & 10556 & 11368 & 6552 & 6874 & 6916 & 3332 & 3360 & 3794 & 62524 & 6947.1 \\
$\mathrm{Ac} / \mathrm{yr}$ & 7.92 & 8.56 & 9.2 & 5.3 & 5.57 & 5.6 & 2.7 & 2.72 & 3.07 & 50.64 & 5.62 \\
$\mathrm{Ha} / \mathrm{yr}$ & 3.18 & 3.44 & 3.69 & 2.13 & 2.24 & 2.24 & 1.1 & 1.1 & 1.23 & 20.35 & 2.04 \\
\hline
\end{tabular}

Notes: $\mathrm{H} / \mathrm{h}=$ Households; Ha-hectares; $\Sigma \mathrm{M}^{3}=$ Total cubic meters; $\mathrm{Ac} / \mathrm{yr}=$ acres per year; $\mathrm{Avg}=$ average; ${ }^{\star}$ Exclusive charcoal burning and illegal logging.

\subsubsection{Inadequate Community Involvement}

Communities' involvement in VLFR management was examined. Perceptions about their involvement varied among stakeholders. The key informants were satisfied with communities involvement and participation. However, $70 \%$ of household's respondents were not in agreement with leaders views. As for Cleaver (2001), token or nominal community involvement and/or participation can legitimize top-down decision making, and hence revive centralism system within community based forests management.

\subsubsection{Land Conflicts}

Different types of conflicts as perceived by communities were observed in the study area (Table 4). Conflicts and levels of conflicts varied among villages. Communities further classified the conflicts at three levels, that very significant (1), significant (2) and not significant (3). These were conflicts between agricultural versus pastoralists; game reserve versus other communities' land uses and VLFRs schemes versus other land uses. The increased land conflicts in the study area could probably be explained by shortage of land within villages, inadequate involvement of communities in conservation planning, inadequate conservation education, and lack or inadequate direct benefits from their VLFRs. Sosovele and Ngwale (2002) observed that forest reserves in Mbarali district and adjacent areas including the Mapogoro, Chimala and Itamboleo wards in the Usangu flats 
Table 4. Types of land conflicts in the study area.

\begin{tabular}{|c|c|c|c|c|}
\hline \multirow{2}{*}{ Type of Conflict } & \multirow{2}{*}{ Competing Parts } & \multicolumn{3}{|c|}{ Level of Conflict } \\
\hline & & Mabadaga & Mbuyuni & Itamboleo \\
\hline $\begin{array}{l}\text { Agricultural communities } \\
\text { versus pastoralism }\end{array}$ & Itamboleo versus Matebete village & 2 & 3 & 1 \\
\hline $\begin{array}{l}\text { Game reserve versus other } \\
\text { land uses }\end{array}$ & Mbuyuni versus KGR & 3 & 1 & 3 \\
\hline Other land uses Versus CBFs & $\begin{array}{l}\text { VNRCs versus Itamboleo and } \\
\text { Mbuyuni villages }\end{array}$ & & & \\
\hline project lands & $\begin{array}{l}\text { Mabadaga versus the locals within } \\
\text { and out village }\end{array}$ & 2 & 1 & 1 \\
\hline
\end{tabular}

KGR $=$ Kitulo Game Reserve VNRC = Village Natural Resource Committee $1=$ very significant $2=$ significant $3=$ not significant.

are under threat of agricultural encroachment, charcoal burning and pastoralist activities. These anthropogenic activities if not checked could further degrade the VLFRs in the study area.

\subsection{Suggestions for Improving VLFR Management and Sustainability}

The establishment of VLFRs in Tanzania; the democratization of forest management; was regarded a result of external and internal forces (e.g. resistant of Duru-Haitemba village to gazettement of their forests) and a pressure of world organizations (e.g. World Bank and IMF). With emphasis that adherence to the pressure's condition was forceful does not make the programs obsolete. It is this fact that the study suggest that Mbarali district council has to ensure that village's forest bylaws are approved quickly and assist villages to prepare their FMPs for effective management. The study put forward also that VNRCs members require further training on their roles and responsibilities in VLFRs management. Committees ought to carry out more discussions with the village populations about their roles and responsibilities in forest management to widen community's understanding of relationship between the reserves, communities and committees.

The VLFRs management schemes should conduct more public meeting at village and sub villages to enhance effective participation and involvement of wider community (especially women) in the reserves activities. Both the government and local and international organizations should strive to build community capacities (e.g.by facilitating productivity of their income generating activities) to enhance broader participation of members, household and local institution's capital; to improve productivity of community's around VLFRs, and foster social and economic diversifications to reduce too much dependence over forest reserve for social and economic incomes. The study also suggests forests Act of 2002 to be reviewed to make village natural resource committees accountable and responsible to the wider community rather than village councils. This can 
make benefits sharing mechanism more transparent and equitable, hence reduce elite capture.

\section{Conclusion}

The establishment of VLFRs partially reflected community's interests and feeling of necessity as the conservation ideas were not born and suggested by local authorities based on their sense of area's ecological importance and availability of funds for an activity. As a result, forest degradation through firewood harvest and agricultural encroachments persisted despite the presence of guards. However, the existence of watchmen in VLFRs Mabadaga, Mbuyuni and Itamboleo villages consolidates an insight that communities' sense of ownership is fairly minimal and forest reserves are vulnerable island-like-patches that may disappear if proper involvement of communities remains as it is.

Further, only little efforts to deliberate social and economic capacity building around communities surrounding forest conservations existed. Lack of communities' capacitation on energy, agriculture and financial services propelled dependence over VLFRs and the reserves around the study area (e.g. Kipengele Game Reserve for energy, income and agriculture).

VNRC's responsibilities were misunderstood, mistranslated and mis-transmitted and hence evoluted to forest managers, guards and finer of delinquents than coordinators of the forest conservation practices and processes. It is on these bases that VNRCs members require further training on their roles and responsibilities in VLFRs management. Committees should also conduct more discussions with the village populations about the roles and responsibilities to widen community's understanding of relationship between VLFRs and the committees.

Both the government and local and international organizations should strive to build community capacities (e.g. by facilitating productivity of their income generating activities) to enhance broader participation of members, household and local institution's capital; to improve productivity of community's around VLFRs, and foster diversifications for both social and economic activities to reduce too much dependence of communities from forest for social and economic incomes.

\section{Conflicts of Interest}

The authors declare no conflicts of interest regarding the publication of this paper.

\section{References}

Ahrends, A., Burgess, N. D., Milledge, A. S. H., Bulling, M. T., Fisher, B., Smart, J. C. R., Clarke, P. G., Mhoro, E. B., \& Lewis, L. S. (2010). Predictable Waves of Sequential Forest Degradation and Biodiversity Loss Spreading From African City. PNAS, 107, 14556-14561.

Blomley, T., \& Idd, S. (2009). Participatory Forest Management in Tanzania 1993-2009: Lessons Learned and Experience to Date. Dar-Es-Salaam: MNRT. 
Cleaver, F. (2001). Institutions, Agency and the Limitations of Participatory Approaches to Development (pp. 17-18). London: Zed Books.

FAO (2015). Global Forest Resources Assessment 2015 (pp. 1-3). Forest Management in Gambia, Banjul: UNESCO Institute of Lifelong, Learning.

FRA (2011). Reforming Forest Tenure. Rome: Global Forest Resource Assessment.

Global Forest Resource Assessment (2010). Main Report, Food and Agriculture Organization of the United Nations, Rome.

Ishengoma, R. C. (1982). Charcoal as a Domestic Fuel in the Municipal of Dodoma, Tanzania. Forestry Record No. 4, Dar-es-salaam: Division of Forestry, University of Dar-es-salaam.

Kajembe, G. K., Nduwamungu, J., \& Luoga, E. J. (2005). The Impact of Community-Based Forest Management and Joint Forest Management on the Forest Resource Base and Local People's Livelihoods: Case Studies from Tanzania. CASS/PLASS Commons Southern Africa Occasional Paper Series No. 8, Cape Town: Centre for Applied Social Sciences (CASS) and Program for Land and Agrarian Studies Harare, Zimbabwe, and Cape Town, South Africa: (PLASS).

Luoga, E. J., Witkowisk, E. T. F., \& Balkwill, K. (2002). Economics of Charcoal Production in Miombo Woodland of Eastern Tanzania: Some Hidden Costs Associated with Commercialization of Resources. Ecological Economics, 35, 243-257.

Lusambo, L. P., Monela, G. C., Katani, J., \& Mombo, F. (2000). Socio-Economic Analysis of Land Use Factors Causing Degradation Deforestation of Miombo Wood Land in Kilosa District, Tanzania. Tanzania Journal of Forestry and Nature Conservation, 76, 28-39.

Roe, D., Nelson, F., \& Sandbrook, C. (2009). Community Management of Natural Resource in Africa: Impacts, Experience and Future Directions (p. 48). Natural Resource Issues No. 18, London: International Institute for Environment and Development (IIED).

URT (2007). Community Based Forest Management Guideline (pp. 1-57). Dar-es-salaam: Ministry of Natural Resource and Tourism.

Willy, A. L. (2006). Land Rights Reform and Governance in Africa: How to Make It Work in the 21st Century? United Nations Development Programme.

World Bank (2010). Implementation Completion Report, Tanzania Forest Conservation and Management Project and Eastern Arc Forests Conservation and Development Project (Report No. ICR00001507). Washington DC.

World Bank (2011). Project Performance Assessment Report Tanzania Forest Conservation and Management Project-Eastern Arc Forest Conservation and Management Project. Independent Evaluation Group, Public Service.

World Resource Institute (2005). The Wealth of the Poor Managing Ecosystems to Fight Poverty. 